\title{
Supplementation of dairy cows grazing an alpine pasture: Effect of concentrate level on milk production, body condition and rennet coagulation properties
}

\author{
Stefano Bovolenta ${ }^{\text {a*, }}$, Walter Ventura ${ }^{\mathrm{b}}$, Edi Piasentier ${ }^{\mathrm{a}}$, \\ Franco Malossinia \\ "Dipartimento di Scienze della Produzione Animale (DISPA), Università di Udine, \\ via S. Mauro 2, 33010 Pagnacco (UD), Italy \\ ${ }^{b}$ Istituto Agrario, via E. Mach 2, 38010 S. Michele all'Adige (TN), Italy
}

(Received 1 October 1997; accepted 6 February 1998)

\begin{abstract}
The aim of this research was to measure, in terms of milk quantity and quality and variations of live weight (LW) and body condition score (BCS), the effect of offering different levels of concentrate to dairy cows grazing at high altitude. The experiment, which lasted 8 weeks, was conducted on a pasture located at an altitude of $1800-2200 \mathrm{~m}$. Three groups of 10 Italian brown cows were fed different levels of concentrate offered above a production of $7 \mathrm{~kg}$ energy corrected milk (ECM), which was assumed to be provided by the pasture: group L, $1 \mathrm{~kg}$ of concentrate as fed every $2.3 \mathrm{~kg}$ ECM; group M, $1 \mathrm{~kg}$ every $2.0 \mathrm{~kg} \mathrm{ECM}$; and group $\mathrm{H}, 1 \mathrm{~kg}$ every $1.7 \mathrm{~kg}$ ECM. Botanical and chemical measurements were performed on the grazed grass and temperature and rainfall recorded. The nutritive value of the herbage fell from $0.90 \mathrm{UFL} / \mathrm{kg} \mathrm{DM}$ at the beginning of the trial to $0.65 \mathrm{UFL} / \mathrm{kg} \mathrm{DM}$ at the end. The mean daily production of ECM was more than $1 \mathrm{~kg}$ higher for group H with respect to the other two groups (mean $17.2 \mathrm{~kg}$ ). The protein level increased slightly with the increasing proportion of concentrate (difference 0.11 percentage points between groups $L$ and $H$ ). The times for aggregation $\left(k_{20}\right)$ and gel firmness $\left(a_{30}\right)$ were better, but not significantly, in the milk from group $\mathrm{H}$. The mean changes in LW and BCS were nil for group $\mathrm{L}$ and positive and increasing with the increasing level of concentrate in groups $\mathrm{M}$ and $\mathrm{H}$. According to estimates based on productive performance and BCS variations, the overall mean herbage consumption was $12.2 \mathrm{~kg} \mathrm{DM}$, which would have supported a production of $7.4 \mathrm{~kg}$ ECM. (@) Elsevier/Inra)
\end{abstract}

dairy cow / pasture / supplementation / milk yield / milk quality / body condition score

\footnotetext{
* Correspondence and reprints

Tel: ++39 434 650110; fax: ++39 434 660614; e-mail: stefano.bovolenta@dpsa.uniud.it
} 
Résumé - Supplémentation des vaches laitières au pâturage alpin : effet du niveau du concentré sur la production laitière, l'état corporel et l'aptitude du lait à la coagulation. Considérant que les pâturages de montagne ne sont pas capables de couvrir les besoins des vaches en lactation, le but de cette étude a été de vérifier les réponses des animaux - en termes de quantité et de qualité du lait, ainsi que de variations d'état corporel - à la supplémentation de différents niveaux de concentré. L'essai a été conduit pendant les mois de juillet et août, pendant huit semaines, sur un pâturage situé à $1800-2200 \mathrm{~m}$ dans la région des Alpes orientales italiennes. Trente vaches en lactation de race Brune italienne ont été réparties en trois groupes de dix animaux recevant différents niveaux de concentré au-dessus d'une production de $7 \mathrm{~kg}$ de lait corrigé pour l'energie (ECM), supposée assurée par le pâturage : groupe L, $1 \mathrm{~kg}$ de concentré pour $2,3 \mathrm{~kg}$ de ECM ; groupe $\mathrm{M}, 1 \mathrm{~kg}$ pour $2,0 \mathrm{~kg}$ de ECM ; groupe $\mathrm{H}, 1 \mathrm{~kg}$ pour $1,7 \mathrm{~kg}$ de ECM. La quantité du concentré a été calculée toutes les deux semaines, en fonction des contrôles de production laitière. Le poids vif ( $\mathrm{LW}$ ) et la note d'état corporel (BCS) ont été déterminés au début et à la fin de I'essai. Les caractéristiques moyennes de l'herbe (tableau II), determinées sur des échantillons prélevés suivant la technique du hand plucking, se sont progressivement dégradées : la valeur nutritive est passée de 0,90 UFL/kg MS, à 0,65 UFL/kg MS à la fin de l'essai. La production moyenne par jour (tableau III) a été presque égale dans les groupes $\mathrm{L}$ et $\mathrm{M}$ (moyenne de 17,2 kg ECM), tandis qu'elle a été supérieure de plus de $1 \mathrm{~kg}$ dans le group $\mathrm{H}$, avec un rendement marginal du concentré de $0,7 \mathrm{~kg}$ ECM par $\mathrm{kg}$. La teneur en protéines s'est légèrement accrue avec l'apport de concentré (différence de $1,1 \mathrm{~g} / \mathrm{kg}$ entre $\mathrm{L}$ et $\mathrm{H}$ ), tandis que les teneurs en matières grasses, lactose et urée sont restées pratiquement sans changement. Le temps de raffermissement du caillé $\left(\mathrm{k}_{20}\right)$ ainsi que sa fermeté $\left(\mathrm{a}_{30}\right)$ ont été meilleurs dans le lait du groupe $\mathrm{H}$, bien que les différences ne soient pas significatives (tableau IV). Les variations moyennes de LW et de BCS (tableau III) ont été nulles dans le groupe $\mathrm{L}$, mais positives et croissantes à l'augmentation du niveau de concentré dans les groupes M et L. Selon une évaluation basée sur la production du lait et sur la variation de BCS, l'ingestion moyenne de l'herbe a été de $12,2 \mathrm{~kg} \mathrm{MS}$, ce qui aurait assuré une production de 7,4 kg ECM. Dans des conditions analogues à celles de cet essai, il est par conséquent indispensable de complémenter avec des concentrés au-dessus de ce niveau de production. (@) Elsevier/Inra)

vache laitière / pâturage / supplémentation / production laitière / qualité du lait / note d'état corporel

\section{INTRODUCTION}

The problems associated with the utilization of pasture by dairy cows have been widely studied in lowland environments $[3,17,22]$, but the conditions are very different for mountain pastures, which are still commonly used during the summer period in all alpine regions. In effect, pastures located at high altitudes are not only considerably less productive for various reasons - colder climate, frequent rocky outcrops, less possibility of correct management - but grazing them also requires that the animal uses more energy for walking on sloping ground. As a consequence, the herbage alone is only capable of supporting modest milk pro- duction levels. Summer grazing on mountain pastures thus frequently implies a fall in production, which may be more or less severe according to the production level and the distance from calving [25, 42], and the failure to recover body reserves, with negative effects on the following lactation. In order to overcome the nutritional deficit of the pasture it thus becomes necessary to supplement with concentrate. Due to the changing conditions of the pasture during the season and the depressing effect of the concentrates on the herbage intake, many experimental trials are required before general statements can be made about the quantity of concentrates to be supplied and their effects on productive performance. 
The objective of this trial, conducted on a 'malga' (this term, of paleoeuropean origins, in the central and eastern Italian Alps means a farm composed of the pasture and the buildings for the animals, the staff and possibly also for processing the milk) in the high mountains, was to verify the response, in terms of the quantity and quality of the milk produced, including its rennet coagulation properties and variations of body condition, to the supplementation of different levels of concentrate to lactating cows.

\section{MATERIALS AND METHODS}

\subsection{Pasture and grazing management}

The trial was carried out for 8 weeks in the months of July and August 1996 on a high mountain pasture in the eastern Alps region (malga Juribello, Province of Trento, Italy). The grazable area extended over 157 ha; the lower part, of about 100 ha and located at a mean altitude of $1900 \mathrm{~m}$, is almost flat, with a deep soil, rich in organic matter and at several points very damp; the remainder, reaching up to $2200 \mathrm{~m}$, is steeper with a progressively shallower soil, presenting, at the higher altitudes, outcrops of dolomitic rock. The entire area of the malga is located within the Natural Park 'Paneveggio - Pale di San Martino'. An examination of the botanical composition of the pasture indicated that it was rather variable. Especially near the farm buildings, there were rank patches with Rumex spp. (mainly $R$. alpi$n u s$, and less frequently $R$. acetosa), Senecio alpinus and Stellaria nemorum. The weed Nardus stricta was widespread and generally associated with good herbs such as Festuca rubra, Anthoxanthum odoratum, Phleum alpinum and Poa alpina or, in the damp areas, with Deschampsia cespitosa and various species of Carex (C. fusca, C. flacca, C. pallescens, $C$. stellulata). Legumes were scarce and represented mostly by Trifolium pratense ssp. nivale; species of little grazing interest, such as Potentilla aurea, Potentilla erecta, Campanula barbata and Geum montanum were also common. On the rocky slopes, a Seslerietum, a floristic association typical of poor herbage swards on calcareous substrates, was predominant, with Sesleria varia, Agrostis spp., Anthyllis vulneraria and Dryas octopetala. Thus the pasture was overall rather poor, at least for a large proportion of its area.

During the day, the cows were free to graze over an area of about $110 \mathrm{ha}$, while during the evening and overnight, i.e., in the interval between the evening and morning milkings, the grazing was rotated over the remaining area, close to the buildings, divided into four zones of about 10 ha each.

\subsection{Animals and feeding supplements}

Thirty mature lactating Italian brown cows, part of a herd of 147 animals, were divided into three groups of 10 animals each, on the basis of calving data and the productive performance recorded over the 2 weeks before the trial. The mean data, with the relative standard deviations, were as follows: days in milk 162 (56), milk yield $19.7 \mathrm{~kg}(3.3)$, fat $3.92 \%(0.31)$, protein $3.30 \%(0.22)$, lactose $5.02 \%(0.17)$.

In order to calculate the rations, on the basis of previous experience and the stocking rate, it was prudently assumed that the pasture alone was capable of supporting a mean production of at least $7 \mathrm{~kg}$ of energy corrected milk (ECM), assuming $1 \mathrm{~kg} \mathrm{ECM}=750 \mathrm{kcal}[4]$. The production exceeding $7 \mathrm{~kg}$ was covered by three different levels of concentrate $(0.91$ UFL/ $/ \mathrm{kg}$ as fed): low group (L) $1 \mathrm{~kg}$ per $2.3 \mathrm{~kg}$ ECM; medium (M) $1 \mathrm{~kg}$ per $2.0 \mathrm{~kg} \mathrm{ECM}$; high (H) $1 \mathrm{~kg}$ per $1.7 \mathrm{~kg}$ ECM. The quantities of concentrate were revised at 2 -week intervals, following the effective milk production. The concentrate was offered twice daily during milking, with any refusals being recorded.

\subsection{Measurements, estimates and chemical analysis}

The live-weight ( $\mathrm{LW}$ ), on 2 consecutive days, and body condition score (BCS [8]) were determined at the beginning and end of the trial. BCS values were obtained by two independent evaluators. The mean initial values were $558 \mathrm{~kg} \mathrm{LW}($ S.D. $=43$ ) and $3.18 \mathrm{BCS}$ points (S.D. $=0.35$ ) respectively.

At 2 -week intervals the milk yicld was recorded and samples were collected twice daily for 2 consecutive days. Individual samples were analyzed for fat, protein, lactose 
and urea with an infrared Milk-o-scan apparatus. On the morning milk samples, the titratable acidity, expressed as ${ }^{\circ} \mathrm{SH} / 50 \mathrm{~mL}$, and the rheological parameters, rennet clotting time $(r)$, time for aggregation $\left(k_{20}\right)$ and gel firmness $\left(a_{30}\right)$, were determined with a Foss Electric Formagraph [29].

Samples of herbage were hand-plucked by simulating animal grazing at about 3-week intervals. The samples were collected four times per day, at about $09.00,11.00,19.00$ and $21.00 \mathrm{~h}$. At each sampling time, 20 samples of herbage were collected: the 80 daily samples were classified botanically and then bulked and dried in a forced draught oven at $60^{\circ} \mathrm{C}$ prior to analysis for proximate composition [1] and fiber components [12]. The same determinations were also performed on four samples of the concentrate. The organic matter digestibility (OMD) of the herbage was detcrmined in vitro with the rumen liquid-pepsin technique [39]. The OMD of the concentrate was estimated from the concentrations of the fiber components and ether extract [11].

The supposed herbage intake was obtained by a reverse calculation [37] based on Inra standards for maintenance and production [16], the energy value of variations in BCS [5] and the mean nutritive value of the herbage and concentrates. In order to account for the energy costs of walking, the maintenance requirement was increased by $25 \%[18,42]$.

The temperature and precipitation were recorded daily with an automatic weather station. The average daily temperature was calculated as the mean of the maximum and minimum values.

\subsection{Statistical analysis}

The data were analyzed with the following models:

- milk production and composition:

$$
y=\mu+A_{i}+b x_{i j}+\varepsilon_{i j}
$$

- rennet coagulation properties $\left(r, k_{20}\right.$ and $a_{30}$ ), titratable acidity and variations of $L W$ and $\mathrm{BCS}$ :

$$
y=\mu+A_{i}+\varepsilon_{i j}
$$

where: $\mu$, general mean, $A_{i}$, feeding treatment ( $i=1, \ldots, 3), b x_{i j}$, covariates (data recorded during the preliminary period) and $\varepsilon_{\mathrm{ij}}$, error.

\section{RESULTS}

\subsection{Meteorological recordings}

The temperature was particularly low, with a minimum value of $0{ }^{\circ} \mathrm{C}$ in July and a mean for the whole experimental period of $9.3{ }^{\circ} \mathrm{C}$, with a small increase between July and August $\left(9.1^{\circ} \mathrm{C}\right.$ vs. $\left.9.5^{\circ} \mathrm{C}\right)$. Rainfall was high: in 8 weeks, $307 \mathrm{~mm}$ were recorded, distributed fairly evenly (164 $\mathrm{mm}$ in July and $143 \mathrm{~mm}$ in August).

\subsection{Feed composition}

Table I presents the botanical composition of the grazed herbage, estimated from the hand-plucked samples. As expected, Gramineae, including the less valuable species such as Nardus stricta and Deschampsia cespitosa, were the main component of the diet over the entire period, although Fabaceae (legumes) and Rosaceae were also well represented. Rumex spp. were consumed to a small extent.

The mean chemical composition of the grazed herbage samples is reported in table $I I$. The protein content, always rather high, showed a slight trend to diminish as the trial progressed. The variations in the fiber fractions were in the opposite sense and more accentuated: the NDF increased by 11.1 percentage points over the 2-month period and the ADF increased by 6.2 points. As a consequence, the digestibility of the organic matter diminished progressively, passing from 73 to $56 \%$, as did the net energy, falling from 0.90 to $0.65 \mathrm{UFL} / \mathrm{kg} \mathrm{DM}$. The chemical composition, feeding value and the components of the concentrate are also presented in table II.

\subsection{Intake, milk yield, LW and BCS changes}

The performance of the three groups is shown in table $1 I I$. The daily production was almost identical in groups $\mathrm{L}$ and $\mathrm{M}$, 
Table I. Botanical composition of grazed herbage ${ }^{1}$.

\begin{tabular}{lcccc} 
& \multicolumn{4}{c}{ Sampling date } \\
\cline { 2 - 5 } & $25 / 06$ & $17 / 07$ & $04 / 08$ & $24 / 08$ \\
\hline Gramineae, good quality $^{2}$ & $* * * *$ & $* * * *$ & $* * * *$ & $* * *$ \\
Gramineae, poor quality $^{3}$ & $* * *$ & $* * *$ & $* *$ & $* *$ \\
Fabaceac $^{4}$ & $* *$ & $* *$ & $* *$ & $* *$ \\
Asteraceae $^{5}$ & $*$ & $*$ & $* *$ & $* *$ \\
Rosaceae $^{6}$ & $* *$ & $* *$ & $* *$ & $* *$ \\
Polygonaceae $^{7}$ & $*$ & $*$ & $*$ & $* *$ \\
\hline
\end{tabular}

$1 *<5 \%$; ** 6-20\%; *** $21-35 \%$; **** 36-50\% of grazed herbage (as fed). ${ }^{2}$ Phleum pratense, Poa pratensis, Festuca arundinacea, Festuca rubra, ${ }^{3}$ Nardus stricta, Deschampsia cespitosa; ${ }^{4}$ Trifolitum repens, Trifolitum pratense; ${ }^{5}$ Hie racium villosum, Leontoden hispidus, Taraxacum officinale; ${ }^{6}$ Alchemilla valgare $;{ }^{7}$ Rumex alpinus.

Table II. Chemical composition of concentrate and grazed herbage.

\begin{tabular}{lccccc}
\hline & \multicolumn{3}{c}{ Grazed herbage (sampling date) } & Concentrate $^{1}$ \\
\cline { 2 - 4 } & $25 / 06$ & $17 / 07$ & $04 / 08$ & $24 / 08$ & \\
\hline Crude protein (\% DM) & 15.4 & 15.6 & 15.1 & 14.7 & 18.1 \\
Ether extract (\% DM) & 3.5 & 2.7 & 3.5 & 3.0 & 2.7 \\
Crude fiber (\% DM) & 20.5 & 23.1 & 22.7 & 24.0 & 6.8 \\
Ash (\% DM) & 7.6 & 7.2 & 8.3 & 7.4 & 7.6 \\
NDF (\% DM) & 37.4 & 45.3 & 44.6 & 48.5 & 18.8 \\
ADF (\% DM) & 21.2 & 24.7 & 25.9 & 27.4 & 7.2 \\
ADL (\% DM) & 2.9 & 3.1 & 3.7 & 3.1 & 1.8 \\
OMD (\%) & 73 & 66 & 59 & 56 & 92 \\
UFL kg DM ${ }^{-1}$ & 0.90 & 0.80 & 0.69 & 0.65 & 1.05 \\
\hline Com $^{2}$ & & & & & \\
\hline
\end{tabular}

${ }^{1}$ Components: maize $25 \%$, barley $15.5 \%$, extracted soyabean meal $14 \%$, wheat llour middling $12.5 \%$ ' bran $10 \%$, dry sugar beet pulp $10 \%$, maize germ meal $7 \%$, molasses $5 \%$, mineral vitamin supplement $3.5 \%$. ${ }^{2}$ Feed units for lactation.

both in terms of milk and ECM, and more than $1 \mathrm{~kg}$ higher in group $\mathrm{H}$. This higher production level accentuated, as a consequence of the rationing scheme adopted which followed the lactation curve and of a feed-back mechanism, the difference between the quantity of concentrates given to group $\mathrm{H}$ and that given to the other two groups. The milk protein content increased with the level of concentrate, with a difference of 0.11 points between groups $\mathbf{H}$ and $\mathrm{L}$; the fat diminished slightly and not significantly and the lactose remained constant. The daily production of all the components increased with the level of concentrate, but significant differences were observed only for the protein and lactose in group $\mathrm{H}$ with respect to those in groups $\mathrm{L}$ and $\mathrm{M}$. The mean milk urea concentration was $31.4 \mathrm{mg} / 100 \mathrm{~mL}$, with slightly higher values in groups $\mathrm{M}$ and $\mathrm{H}$ in comparison with $\mathrm{L}$, although these dif- 
Table III. Feed intake, milk yield and composition (corrected means), live-weight and body condition score.

\begin{tabular}{|c|c|c|c|c|}
\hline & \multicolumn{3}{|c|}{ Concentrate supplementation } & \multirow{2}{*}{$\begin{array}{l}\text { Standard } \\
\text { error }\end{array}$} \\
\hline & Low & Medium & High & \\
\hline Concentrate ( $\mathrm{kg}$ as fed day ${ }^{-1}$ ) & 4.4 & 5.1 & 6.5 & - \\
\hline Milk $\left(\mathrm{kg} \mathrm{day}^{-1}\right)$ & $17.3^{b}$ & $17.2^{\mathrm{b}}$ & $18.5^{\mathrm{a}}$ & 0.99 \\
\hline $\mathrm{ECM}^{1}\left(\mathrm{~kg} \mathrm{day}^{-1}\right)$ & $17.1^{\mathrm{h}}$ & $17.2^{\mathrm{b}}$ & $18.3^{\mathrm{a}}$ & 0.94 \\
\hline $\mathrm{kg} \mathrm{ECM} / \mathrm{kg}$ concentrate & 3.9 & 3.4 & 2.8 & - \\
\hline Fat $(\%)$ & 3.90 & 3.89 & 3.84 & 0.1835 \\
\hline Protein $(\%)$ & $3.27^{\mathrm{b}}$ & $3.34^{\mathrm{ab}}$ & $3.38^{\mathrm{a}}$ & 0.0970 \\
\hline Lactose $(\%)$ & 4.95 & 5.03 & 4.95 & 0.1417 \\
\hline Fat $(g / d)$ & 669 & 688 & 705 & 55 \\
\hline Protein $\left(\mathrm{g} \mathrm{day}^{-1}\right)$ & $562^{\mathrm{b}}$ & $574^{\mathrm{b}}$ & $623^{a}$ & 39 \\
\hline Lactose $\left(\mathrm{g} \mathrm{day}^{-1}\right)$ & $854^{\mathrm{h}}$ & $867^{\mathrm{b}}$ & $919^{\mathrm{a}}$ & 53 \\
\hline Urea $\left(\mathrm{mg} 100 \mathrm{~mL}^{-1}\right)$ & 29.9 & 32.6 & 31.7 & 4.62 \\
\hline Live weight variation $(\mathrm{kg})^{2}$ & $-1^{h}$ & $+10^{\mathrm{ab}}$ & $+14^{\mathrm{a}}$ & 12.1 \\
\hline Body condition score variation (points) ${ }^{2}$ & $0.00^{\mathrm{b}}$ & $+0.08^{\mathrm{ab}}$ & $+0.25^{\mathrm{a}}$ & 0.2047 \\
\hline Estimated herbage intake $(\mathrm{kg} \mathrm{DM})^{3}$ & 12.3 & 11.9 & 12.3 & 1.32 \\
\hline
\end{tabular}

Table IV. Rennet coagulation properties and titratable acidity.

\begin{tabular}{|c|c|c|c|c|}
\hline & \multicolumn{3}{|c|}{ Concentrate supplementation } & \multirow{2}{*}{$\begin{array}{l}\text { Standard } \\
\text { error }\end{array}$} \\
\hline & Low & Medium & High & \\
\hline Rennet clotting time (r) (min) & $14^{\prime} 20^{\prime \prime}$ & $15^{\prime} 30^{\prime \prime}$ & $15^{\prime} 20^{\prime \prime}$ & $2^{\prime} 06^{\prime \prime}$ \\
\hline Time for aggregation $\left(\mathrm{k}_{20}\right)(\mathrm{min})$ & $84^{\prime \prime}$ & 9'00’' & $7 ’ 36^{\prime \prime}$ & 1'34'” \\
\hline Gel firmness $\left(\mathrm{a}_{30}\right)(\mathrm{mm})$ & 24.6 & 26.0 & 27.6 & 4.51 \\
\hline Titratable acidity $\left({ }^{\circ} \mathrm{SH}\right)$ & 3.2 & 3.2 & 3.5 & 0.34 \\
\hline
\end{tabular}

ferences were not significant due to the high variability. The mean variations in LW and BCS were practically zero in group $\mathrm{L}$ and positive and increasing with the increase of the supplementation level in the other two groups. The mean herbage intake, estimated indirectly from the energy balance, was not significantly different between the three groups, with an overall mean value of $12.2 \mathrm{~kg}$ DM.

\subsection{Rennet coagulation properties}

The values of the rheological parameters and titratable acidity are presented in table IV. The rennet clotting times ( $\mathrm{r}$ ) were almost equal in groups $M$ and $H$, and about 1 min lower in group L. The time for aggregation and the gel firmness $\left(k_{20}\right.$ and $\mathrm{a}_{30}$ respectively) were better in group 
$\mathrm{H}$, with a tendency, for $\mathrm{a}_{30}$, to increase with the increasing level of supplementation. The titratable acidity passed from 3.2 ${ }^{\circ} \mathrm{SH}$ for groups $\mathrm{L}$ and $\mathrm{M}$ to $3.5{ }^{\circ} \mathrm{SH}$ for group $\mathrm{H}$. However, none of these differences were significant.

\section{DISCUSSION}

The correct sampling of herbage from a pasture which reflects the feeding choice of the grazing animal is a difficult problem to resolve. In this trial the evaluation of the quality of herbage consumed by the cows was performed by hand plucking, which appears to be a good technique on mixed pastures with an irregular distribution of different plant species [10,31, 33]. The inevitable imperfect coincidence with the feeding behavior of the animal was overcome, as far as possible, with a high number (80) of daily samples. The measurements performed showed that, in a context of only moderate herbage availability, even grasses of scarce pasture value formed a consistent part of the diet. The intake of legumes, particularly clover, was always consistent, notwithstanding their limited presence in the pasture, thus confirming the dietary preference for these species of recognized high grazing value. These components ensured, for the entire period, an almost constant protein content. In contrast, the fiber fractions increased progressively, reflecting the overall maturation of the sward, and at the same time the OMD diminished dramatically. Similar wide variations in the composition and digestibility of the pasture have also been reported by Ulyatt [40].

The productive response to the three treatments was characterized by the higher milk yield of group $\mathrm{H}$ in comparison with groups $L$ and $M$. The marginal efficiency, taking as reference the mean of $L$ and $M$, was $0.7 \mathrm{~kg}$ milk per $\mathrm{kg}$ of concentrate. In a preceding trial on a different alpine pas- ture, values a little higher than 1 were found [26], while other researchers working on mountain pastures reported a mean value of $0.7[9,15]$. In any case it should be considered that the productive response of grazing animals to concentrate feeding depends on many factors, of which the quality and availability of the herbage and the stage of lactation are predominant $[18,20]$. The protein content of the milk increased with the quantity of concentrate, in agreement with the results of other workers $[6,15,24,38]$. At the same time, the fat content showed a very feeble negative trend: apparently the quantity of fiber ingested with the herbage was sufficient to ensure a normal acetic fermentation in the rumen. As expected, lactose remained an essentially stable component, independent of the quality of the diet. The urea content of the milk, which represents an index of the equilibrium between the energy and protein in the diet [7], was slightly higher in the two groups with the highest levels of concentrate and thus the protein supply. In any case, the values of all groups are within the tolerance limit, $33 \mathrm{mg} / 100 \mathrm{~mL}$, reported by Peyraud [34].

The rennet coagulation properties of milk, notwithstanding the fact that these generally worsen in late lactation [23], were in agreement with the mean values reported for the Italian brown [28, 41]. The time for aggregation and the gel firmness were slightly better in group $\mathrm{H}$, confirming the positive relationship with the protein content $[13,19,21,27,36]$.

Increasing the level of concentrates had a positive influence on the reconstitution of the body reserves, evaluated both in terms of LW and BCS. This latter means of expressing the body situation is preferable as it is not influenced by the digestive tract content, which varies with the stage of maturity of the herbage [5].

The fact that the mean herbage intake was similar in the three experimental groups would appear to indicate that it 
was influenced by some external factor. The particularly low temperatures undoubtedly had a negative influence on the production and thus availability of the herbage; furthermore, the frequent rainfall would have constituted a disturbance factor, reducing the time available for grazing $[2,14,35]$. The fiber content of the herbage may also have represented a limiting factor, as the mean NDF intake was $1.0 \mathrm{~kg} / 100 \mathrm{~kg} \mathrm{LW}$, a value close to the value of $1.1 \mathrm{~kg}$ considered by Mertens [30] to be the threshold for the intake by dairy cows. An average calculation for the entire experimental period indicated that the milk production supported by herbage alone was $7.4 \mathrm{~kg} \mathrm{ECM}$, slightly higher than the $7 \mathrm{~kg}$ predicted before the trial, but nevertheless still a low figure compared with the production supported by lowland pastures, which can exceed $20 \mathrm{~kg}$ [16, 18]. This considerable difference from lowland pastures is not only due to the lower productivity and nutritional value of the alpine pasture itself, but is also a result of the increased energy demand by the grazing animals, caused by the low temperatures and walking on sloping ground.

The dietary protein level never constituted a limiting factor for milk production, as the quantity supplied by the herbage, rich in legumes, and the concentrates always ensured a mean crude protein concentration of more than $15 \%$ of the DM, which, according to the standards of National Research Council [32] covers the requirements for a production of $20 \mathrm{~kg}$ of milk.

\section{CONCLUSIONS}

The results of the trial represent a further confirmation that high altitude alpine pasture is capable of supporting only modest milk yields. In general, it is thus necessary to supplement with concentrate feeds. The highest level adopted, $1 \mathrm{~kg}$ per $2.8 \mathrm{~kg}$ ECM, gave the highest production levels and, at the same time, a good recovery of body reserves. The chemical composition of the milk was favorably influenced by the highest level of concentrate in terms of its protein level and, at least as a trend, its rennet properties; in contrast, no negative effects were observed for the contents of fat or urea. For cows with particularly high milk yields, the low energy intake from herbage would require very high levels of concentrate, with possible fermentation and/or metabolic disturbances. This indicates that it would be inopportune to send high yielding animals onto alpine pastures unless feeding systems are available for offering fractional doses of concentrate (out of parlor feeders).

\section{ACKNOWLEDGMENTS}

This project was partly supported by the Consiglio Nazionale delle Ricerche (CNR). The authors wish to thank dott. C. Valorz (Federazione Allevatori, Trento) for the disposal of the malga Juribello, dott. D. Tonietto (Associazione Nazionale Allevatori Razza Rendena) for helping with the BCS recordings and dott. D. Orlandi (Istituto Sperimentale per l'Assestamento Forestale c per l'Alpicoltura) for the botanical examination of the pasture.

\section{REFERENCES}

11) AOAC. Official methods of analysis. 15th edn., AOAC, Arlington, Virginia, USA, 1990. $1298 \mathrm{p}$.

121 Arnold G.W.. Dudrinski M.L., Ethology of frec-ranging domestic animals, Elscvier Publ., Amsterdam, 1978, $198 \mathrm{p}$.

131 Arriaga-Jordan C.M., Holmes W., The effect of concentrate supplementation on high yielding dairy cows under two system of grazing, J. Agric. Sci. Camb. 107 (1986) 453-463.

14 Bickel H., Fat-corrected milk (FCM), an inaccurate and confusing term, Liv. Prod. Sci. 18 (1988) $311-313$. 
[5] Chilliard Y., Rémond J., Agabriel J., Vérite R., Variations du contenu digestif et des réserves corporelles au cours du cycle gestation-lactation, Bull. Tech. CRZV Theix, Inra 70 (1987) 117-131.

[6] Colin O., Laurent F., Vignon B., Alimentation et maîtrise de la qualité protéique et technologique des laits en élevage, Ann. Zootech. 42 (1993) 37 I-378.

[7] DePeters E.J., Cant J.P., Nutritional factors influencing the nitrogen composition of bovine milk: a review. J. Dairy Sci. 75 (1992) 2043-2070.

181 Edmonson A.J., Lean I.J., Weaver L.D., Furver T., Webster G., A body condition scoring for Holstein dairy cows, J. Dairy Sci. 72 (1989) 68-78.

[9] Garel J.P., Hoden A., Pâturage en zone de montagne: niveaux de chargement et de complémentation pour des vaches laitières, Bull. Tech. CRZV Theix, Inra 62 (1985) 35-46.

[10] Gibb M.J., Treacher T.T., The effect of herbage allowance on herbage intake and performance of lambs grazing perennial ryegrass and red clover sward. J. Agric. Sci. Camb. 86 (1976) 355-365.

[11] Giger-Reverdin S., Aufrère J., Sauvant D., Demarquilly C., Vermorel M., Pochet S., Prévision de la valeur énergétique des aliments composés pour les ruminants. Inra Prod. Anim. 3 (1990) 181-188.

[12] Goering H.K., Van Soest P.J.. Forage fiber analyses (apparatus, reagent, procedures and some applications), US Department of Agriculture, Agriculture Handbook No. 379, 1970, $12 \mathrm{p}$.

[13] Grandison A.S., Anderson M., Ford G.D., Newell L., Interrelationship between the diet fed to cows, composition and properties of milk composition and quality of cheshire cheese from farmhouse manufacturers. J. Dairy Res. 52 (1985) 587-593.

114] Hafez E.S.E., Bouissou M.F., The behaviour of cattle, in: Hafez E.S.E. (Ed.), The behaviour of domestic animals. Balliere and Tindal, London, 1975, pp. 203-245.

[15] Hauwuy A., Bornard A., Coulon J.B., Haltel L., Performances des vaches laitières en alpage: effet du niveau de la complémentation en aliment concentré, Inra Prod. Anim. 6 (1993) 289-295.

[16] Hoden A.. Coulon J.B., Faverdin Ph., Alimentation des vaches laitières, in: Jarrige R., (Ed.), La vache laitière. Inra Publ., Versailles, 1988, pp. 87-98.

[17] Hoffman K., Muller L.D., Fales S.L., Holden L.A., Quality evaluation and concentrate supplementation of rotational pasture grazed by lactating cows, J. Dairy Sci. 76 (1993) 2651-2663.
[18] Holmes C.W., Wilson G.F., Milk production from pasture, Butterworths, New Zealand, 1984. $319 \mathrm{p}$.

[19] Hurtaud C., Rulquin H., Delaite M., Vérité R., Appréciation de l'aptitude fromagère des laits de vaches individuels. Tests d'aptitude fromagère et rendement fromager de fabrication. Ann. Zootech. 44 (1995) 385-398.

[20] Journet M., Demarquilly C., Grazing, in: Broster H. Swan H. (Eds.). Feeding Strategy for the High Yielding Dairy Cows, EEAP Publ no. 25. 1979. pp. 295-321.

(21) Laurent F., Coomans D., Gardeur J.N., Vignon B., Composition azotée et caractéristiques technologiques du lait de vache en relation avec la nature et le niveau d'apport de l'aliment concentré, Lait 72 (1992) 175-183.

[22] Leaver J.D., Campling R.C., Holmes W., Use of supplementary feeds for grazing dairy cows, Dairy Sci. Abstr. 30 (1968) 355-36l.

[23] Lucey J., Cheesemaking from grass based seasonal milk and problems associated with late-lactation milk, J. Soc. Dairy Techn. 49 (1996) 59-64.

[24] Macheboeuf D., Coulon J.B.. D'Hour P., Effect of breed, protein genetic variants and feeding on cow milk coagulation propertics. J. Dairy Res. 60 (1993) 43-54.

[25] Malossini F., Bovolenta S.. Pradi P.P., Piras C.. Effetto dell'alpeggio sulla produzione di latte di bovine di razza Bruna, Zoot. Nutr. Anim. 18 (1992) 259-265.

126| Malossini F., Bovolenta S., Piras C., Ventura W. Effect of concentrate supplementation on herbage intake and milk yield of dairy cows grazing an alpine pasture, Liv. Prod. Sci. 43 (1995) 119-128.

[27] Malossini F.. Bovolenta S., Piras C., Dalla Rosa M., Ventura W., Effect of diet and breed on milk composition and rennet coagulation properties, Ann. Zootech. 45 (1996) 2940.

[28] Mariani P., Pecorari M., Fossa E., Le caratteristiche di coagulazione del latte in rapporto allo stadio della lattazione e ai livelli di produzione, Sci. Tecn. Latt. Cas. 33 (1982) 409-425.

[29] McMahon D.J., Brown R.J., Evaluation of Formagraph for comparing rennet solutions, J. Dairy Sci. 65 (1982) 1639-1642.

[30] Mertens D.R., Prediction intake and digestibility using mathematical models of ruminal function, J. Anim. Sci. 64 ( 1987) 1548-1558.

[31] Minson D.J., Intake of grazed forage, in: Cunha T.J. (Ed.), Forage in ruminant nutrition, Academic Press, San Diego, California, USA, 1990, pp. 60-84.

132] National Research Council, Nutrient Requirements of Dairy Cattle, 6th revised edn., National Academy Press, Washington, DC, $1989,155 \mathrm{p}$. 
[33] Penning P.D., Le Du Y.L.P., Animal based techniques for estimating herbage intake, in: Herbage intake handbook, British Grassland Society, Hurley, Maidenhead, Berkshire, UK, 1982, pp. 37-75.

[34] Peyraud J.C., Maïs-fourrage : la dégradabilité au banc des accusés, Cultivar 2000 Élevages 242 (suppl. 9), 1989, 40-42.

[35] Peyraud J.L., Delaby L., Delagarde R., Quantitative approach of dairy cows nutrition at grazing: some recent developments, Proceeding of the Joint Meeting Intake/Ecology groups, Dublin, September, 1996, in press.

136] Politis I., Ng-Kwai-Hang K.F., Effects of somatic cell count and milk composition on the coagulating properties of milk, J. Dairy Sci. 71 (1988) 1740-1746.

[37] Reeves M., Fulkerson W.J., Kellaway R.C., Dove H., A comparison of three techniques to determine the herbage intake of dairy cows grazing kikuyu (Pennisetum clandestimum) pasture, Austr. J. Exp. Agric. 36 (1996) 23-30.
[38] Spörndly E., Effect of diet on milk composition and yield of dairy cows with special emphasis on milk protein content, Swed. J. Agric. Res. 19 ( 1989 ) 99-106.

[39] Tilley J.M.A., Terry R.A., A two stage technique for the in vitro digestion of forage crops, J. Br. Grassl. Soc. 18 (1963) 104-111.

[40] Ulyatt G.W., The feeding value of temperate pasture, in: Morley F.H.W. (Ed.), Grazing animals, Elsevier, Amsterdam, 1981, pp. 125-143.

[41] Zannoni M., Annibaldi S., Standardization of the renneting ability of milk by Formafraph. Note I, Sci. Tecn. Latt. Cas. 32 (1981) 79-94.

[42] Zemp M., Leuenberger H., Künzi N., Blum $\mathrm{W}$., Influence of high altitude grazing on productive and physiological traits of dairy cows. I. Influence on milk production and body weight, J. Anim. Breed Genet. 106 (1989) $278-288$. 